Supporting information

\title{
Proteins and protein-rich biomass as environmental-friendly adsorbents selective for precious metal ions
}

\author{
Tatsuo Maruyama," Hironari Matsushita, Ichiro Kamata, Yukiko Shimada, Saori \\ Sonokawa, Noriho Kamiya and Masahiro Goto*
}

$\underline{\mathrm{S} 1 .}$ Effect of ionic strength on the $\mathrm{Au}^{3+}$ and $\mathrm{Pd}^{2+}$ adsorption to Lysozyme.

The adsorption of metal ions was conducted separately (not competitive). Lysozyme concentration was $0.2 \mathrm{~g} / \mathrm{l}$. Each concentration of metal ion was $10 \mathrm{ppm}$. pH was set at 4 . The $\mathrm{Au}^{3+}$ - and $\mathrm{Pd}^{2+}$-adsorption to lysozyme was independent of the ionic strength, suggesting that the adsorption was not due to electrostatic interaction. Similar profiles were observed for other kinds of proteins.

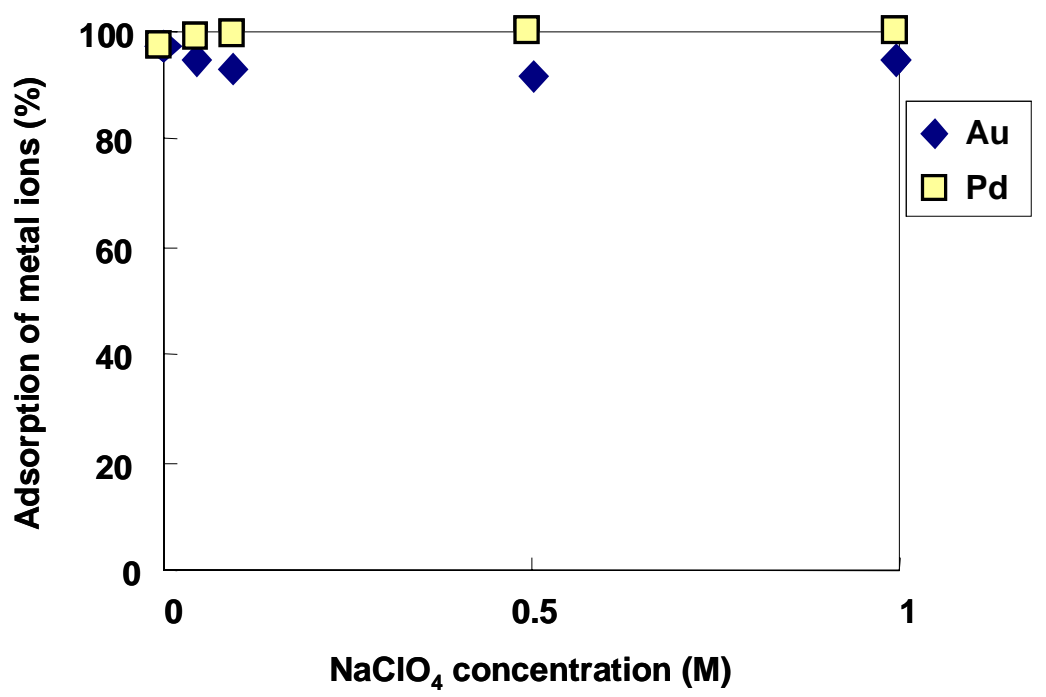

Fig. S1 Effect of the $\mathrm{NaClO}_{4}$ concentration on the Au3+ and $\mathrm{Pd} 2+$ adsorption to Lysozyme. 


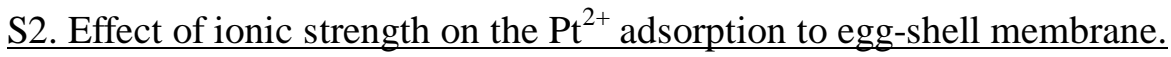

The adsorption of $\mathrm{Pt}^{2+}$ was conducted using $1 \mathrm{mg} / \mathrm{ml}$ egg-shell membrane and $10 \mathrm{ppm}$ $\mathrm{Pt}^{2+}$ at $\mathrm{pH}$ 1.0. After the adsorption, the solution was filtrated. The free $\mathrm{Pt} 2+$ concentration in the filtrate was determined by ICP-emission spectroscopy. Since the presence of $\mathrm{NaClO}_{4}$ reduced the $\mathrm{Pt}$ adsorption to the egg-shell membrane, the $\mathrm{Pt}$ adsorption in the absence of $\mathrm{NaClO}_{4}$ was probably due to electrostatic interaction between Pt ions and the egg-shell membrane.

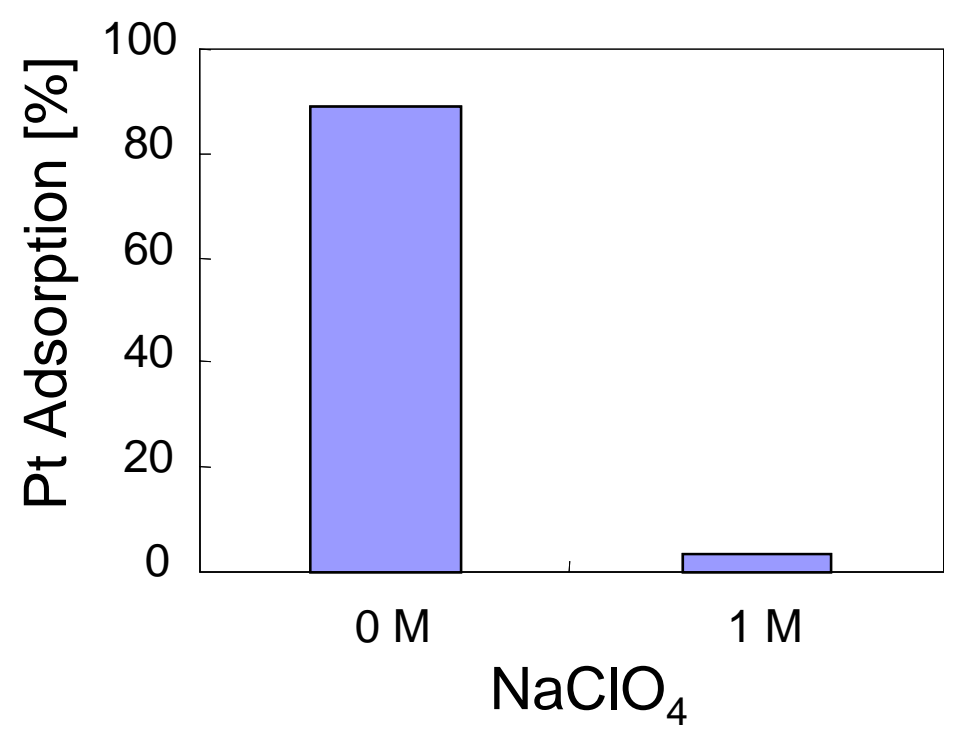

Fig. S2 Effect of $\mathrm{NaClO}_{4}$ on the $\mathrm{Pt}^{2+}$ adsorption to egg-shell membrane. 